Journal of African Real Estate Research
Volume 6, Issue 1
J A R E R Recial Issue: Women in African Real Estate and Urban
Development Research

\title{
Property Taxation Imperatives for Africa: A Study of Four Cities
}

\author{
Basirat Ashabi Oyalowo ${ }^{1}$, Damilola Shittu ${ }^{2}$ and Emmanuel Abdul ${ }^{3}$ \\ ${ }^{1-3}$ Department of Estate Management, University of Lagos, Nigeria
}

To cite this article: Oyalowo, B.A., Shittu, D. \& Abdul, E. (2021). Property Taxation Imperatives for Africa: A Study of Four Cities. Journal of African Real Estate Research, 6(1), pp.121-148. DOI: $10.15641 /$ jarer.v6i1.951.

\begin{abstract}
African countries are currently pressured by high urbanisation rates that threaten their ability to address the basic infrastructure and social needs of citizens. Globally, property taxes are utilised as a tool to generate revenue that supports infrastructure provision, but its use has not been effective in Africa. This study examines the trends in property tax administration in cities of four different countries in Africa. It presents an analysis of the lessons that can be learnt and improvements to be made. Using Lagos, Addis Ababa, Dar es Salaam and Kigali as case studies, the study finds that although they have carried out recent property tax reforms which have led to remarkable outcomes in terms of coverage and revenues, opportunities to take advantage of the growing real estate development markets arising from rapid urbanisation have been missed. Lack of intra-governmental co-operation is also a threat to sustaining performance in some cases. The role of local governments has been very contentious with policy changes and controversies. The need for stakeholder involvement and redistributing revenues to local services remains unexplored in all four cases. However, the use of technology in identifying the tax base, updating cadastre, and collection, represents key opportunities to increase effectiveness. Recommendations include strengthening intra-governmental cooperation, using technology to capture new real estate development and supporting local government capacities as strategies to improve property tax policy and administration.
\end{abstract}

Keywords: Property Taxation; Property Tax Reform; Property Tax Policy Guide; Property Tax in Africa

\footnotetext{
${ }^{1}$ boyalowo@unilag.edu.ng
} 


\section{Introduction}

The United Nations (2014) estimates that between 2015 and 2050, the population in African cities will grow by 790 million people and that by 2030 , 12 cities will contain between 5 to 10 million inhabitants compared to just three (Cairo, Kinshasa and Lagos) in 2014. UN-Habitat (2020) notes that because Africa has much lower income levels than other regions with similar levels of urbanisation, it is not reaping all the potential economic development benefits of urbanisation. One manifestation of this is the relatively high percentage of African urban dwellers living in slum conditions. UN-Habitat (2014) projects that more than $50 \%$ of Africa's population is likely to live in slums by 2025. In addition, significant infrastructure deficits affect productivity and quality of life. The African Development Bank (2018) estimates that the continent's infrastructure needs amount to between US\$130-170 billion per year, with a financing gap estimated at \$68-108 billion.

To cope with these challenges, African governments must have access to credible sources of financing to provide capital for basic services, restoration and management of ubiquitous slum communities and provision and maintenance of inclusive and high-impact technology-driven infrastructure. This implies that governments need to be innovative in seeking equitable revenues from both local and foreign sources. Researchers such as Babawale and Nubi (2011), Franzsen and McCluskey (2017a) and Goodfellow (2015) agree that property taxation is a key revenue driver that could support aspirations for economic development at both national and city levels. According to Fjestald et al. (2019), property tax is a tax on ownership, occupation or legal transfer of buildings and land that is commonly charged as annual payments by owners of residential and commercial buildings. It is also an important source of local government and municipal revenue in developed countries, contributing an average of $2.2 \%$ to the GDP of industrial countries (Franzsen \& McCluskey, 2017a). However, its contribution to GDP is quite low at an average of about $0.6 \%$ in developing countries and $0.38 \%$ for Africa (Franzsen \& McCluskey, 2017a). This can be linked to weak tax collection systems that characterise African cities (Oluwadare \& Ojo, 2014; McCluskey \& Franzsen, 2016; Fjeldstad et al., 2017). Thus, tax collection has been a focus of property tax reforms in many African countries (Bird \& Slack, 2004; Babawale \& Nubi, 2011).

Ahmad et al. (2014) note that rapid urbanisation presents an opportunity for tapping into the taxation of built-up land, which has historically been the backbone of local taxation in advanced countries. Property tax would be one means of tapping into the economic opportunities in the emerging African real estate sector provided governments have an effective system for identifying, collecting and accounting for property tax in place. In general, property tax also has an important role to play in tackling urbanisation challenges and unlocking its opportunities by enabling governments to expand their revenue base and, thereby, generate funds that can be used to provide much needed municipal infrastructure. It is also regarded as a 
preferred strategy to strengthen broad based direct taxation in urban Africa (Fjeldstad et al., 2017).

However, property tax is a highly complex system (McCluskey \& Franzsen, 2016). It requires identification of taxable properties, collection of property characteristics, storage of this information and periodic reassessment to capture value changes. African countries work within the constraints of decades of infrastructure decay, a largely informal settlement base (which is usually not captured in their tax base), vulnerable political systems and, sometimes, amoral leadership. Thus, while their current (and potential) performance in property tax administration and revenue generation varies, performance is assessed to be generally low (Franzsen \& McCluskey, 2017a).

Franzsen and McCluskey (2017a) assert that research about property tax is not as widespread in Africa as with other regions of the world. The current study extracts from previous research to analyse the current status of property tax in four cities in sub-Saharan Africa. A key contribution it makes to the extant literature is its use of the UN-Habitat (2011) Land and Property Tax Policy Guide (hereafter referred to as UN-Habitat PT Guide) as an analytical framework to provide an impetus for policy change. The purpose of this article is to assess the current state of property tax in four African cities in different countries, analyse recent improvements, identify changes yet to be made and determine the lessons that can be learnt.

The choice of Addis Ababa (Ethiopia), Dar es Salaam (Tanzania), Kigali (Rwanda) and Lagos (Nigeria) is predicated on their being listed in the World Bank's 2017 Doing Business Report as having relatively stronger property tax performance compared to other cities in their home countries. In addition, these cities have also benefitted from successful implementation of property tax reforms in national or city property tax systems relative to other cities in Africa (Fjeldstad et al., 2017). However, this does not imply that success has been totally achieved throughout their property tax systems. As Franzsen and Youngman (2009) and McCluskey and Franzsen (2016) note, success stories about property tax in Africa can be found in components rather than complete systems, with property tax information being extremely difficult to obtain in many African countries. Recommendations emerge from this study for the policy sector of the selected cities, other African cities and cities in other developing countries whilst also informing advocacy and further studies in this area.

\section{Literature Review}

The poor performance of African tax systems has attracted academic and policy interest in efforts to untangle the causes and remedies. Fjeldstad et al. (2017) show a link between Africa's urbanisation and property taxation, identifying political and administrative constraints facing the development of effective property tax systems. Bird and Slack (2004) provided a study of 25 countries and Franzsen and McCluskey (2017a) analysed the status, challenges and prospects of property taxation in 28 African countries. 
Goodfellow (2017) focussed on the political economy of property taxation in Rwanda and Ethiopia. Researchers like Babawale and Nubi (2011), Balogun (2019), Chemouni (2020), Massawe (2020), Namangaya (2018) and Odimegwu et al. (2018), have carried out studies in specific countries to show the potential of effective property tax administration to fund basic facilities and services.

Over the last decade, many African countries have carried out property tax reforms. These reforms are usually part of an overall local government structure and finance strategy (e.g. Cabo Verde and Tanzania), or part of substantive tax system and land reforms (e.g. Rwanda). Some countries have also carried out reforms independent of other government initiatives (Babawale \& Nubi, 2011). In Lagos, Nigeria, for example, property tax reforms were based on aggressive revenue drives for political survival without reforms in either the land or governance systems (Fjeldstad et al., 2019). On the other hand, Cabo Verde's reforms resulted from a decentralisation drive (Franzsen et al., 2017). In Egypt, meanwhile, constant changes in property tax laws have been carried out in response to socioeconomic and political conditions (Amin et al., 2017). In spite of property taxes being a strong and attractive revenue mobiliser for Africa (Fjeldstad et al., 2017) and reforms being carried out, performance has been low.

In general, the goals of reform include simplification of the tax system, removing inequities and strengthening revenue collection and mobilisation capacity. While the quest for 'good governance' is found in most policy reform statements (Babawale \& Nubi, 2011), it is not always achieved (Goodfellow, 2017). Researchers have searched for the reasons for this by examining the effectiveness of the governance structure underpinning property tax and the effectiveness of the property tax process itself. For instance, Babawale and Nubi (2011) and Plimmer and McCluskey (2010) stress the need for integration of the property taxation and the political economy context of the country. Babawale and Nubi (2011) also stress the need for building on existing political supports and matching property tax reforms with other economic and inter-government fiscal reforms. However, political inference often limits the process, as pointed out by Fjeldstad et al. (2019) and Goodfellow (2017), whereas what is required for success is that the policy environment must be supportive and unambiguous rather than coercive and exploitative. In addition, Fjeldstad et al. (2019) in their analyses of inter-organisational cooperation in revenue collection assert that property tax performance is enhanced if all government agencies involved in property tax policy and administration are more collaborative.

In their comparative study of property tax in four Nigerian states, Odimegwu et al. (2018) caution against the adoption of complex tax policy to underpin property taxation. This echoes the UN-Habitat PT Guide, which emphasises simplicity of property tax systems. Bird and Slack (2004) show from case studies of 25 countries that prerequisites for successful property tax reforms include the existence of a strong tax administration, including a process for 
property identification, assessment, collection and enforcement. This is also the position of Fjeldstad et al. (2017) and Odimegwu et al. (2018) who further show that the tax policy and tax administration should be synchronised, especially if property tax reform is being carried out for the purpose of increasing revenue. In addition, Babawale and Nubi (2011) observe that two critical factors that limit the effectiveness of property tax in developing countries are defective property tax policy and maladministration, with the latter being more critical. They observe that the poor link between tax payment and provision of communal services is one manifestation of such maladministration.

The extant literature is, therefore, clear that both the tax policy environment and the tax administration processes must be effective for meaningful revenue generation in a property tax system. To address the research questions of this study, it is necessary to collate both components into a composite whole that can then be the basis for analysing the property tax systems of the four case studies. The UN-Habitat PT Guide provides a resource to do this.

The UN-Habitat PT Guide identifies two policy imperatives (tax base and rate) and three administrative imperatives (coverage, valuation and collection) as the structures that need to be in place for property tax effectiveness. These imperatives are called 'tax revenue identity elements' in the document and are discussed in the next section. However, the guide does have its limitations to the extent that it is quite generalised because it provides global policy advice. Its recommendations therefore do not always reflect the peculiarities of the politics imbedded in property tax across diverse cities. It is also not based on critical evaluation of performance, rather offering step by step guidelines for initiating and deepening property tax systems. However, it does provide guidance to policy, practice and academia on how property tax systems should be developed, the constraints that are likely to emerge, and alternative strategies for addressing these constraints. To the extent that the present study seeks to provide both policy and technical guidance, it is adopted as an analytical framework for this study.

\subsection{The UN-Habitat Policy Guidance for Effective Land and Property $\operatorname{Tax}$}

The UN-Habitat PT Guide explains the process of initiating, developing, implementing and sustaining an effective land and property tax system. Its 'land and property tax revenue identity perspective' raises questions related to tax policy and tax administration, and proffers recommendations for addressing these questions. We adapt the questions raised as key considerations for entrenching property tax effectiveness in African cities. Thus, the effectiveness of property tax systems in Addis Ababa, Dar es Salaam, Kigali and Lagos are viewed through the lens of the tax revenue identity perspective. The perspective is made up of five core elements divided into two policy elements (tax base and tax rate setting) and three administrative elements (fiscal cadastre, valuation and collection). In this section, we discuss these elements, drawing from the literature, practice in 
different countries and the UN-Habitat PT Guide to establish the critical issues to be addressed if property tax effectiveness is to be achieved.

\subsubsection{The Tax Base}

Tax base refers to the reference property on which the tax is levied. As shown in Table 1, the first issue to address is what is to be taxed (land, immovable improvements or both). The practice varies across countries with some taxing land separately from improvements and others taxing only the improvement (Collier et al., 2017). The UN-Habitat PT Guide recommends that the tax should be levied on land alone where administrative and economic capacity to provide the depth of information required on properties is weak (UNHabitat, 2011).

In considering how tax on the property is to be calculated, Plimmer and McCluskey (2010) identify two assessment types: market (or ad valorem) assessment and non-market assessment. In market assessment, the tax is linked to the capital and rental values of the properties. The UN-Habitat PT Guide asserts that market value approaches are appropriate for countries that have a vibrant real estate market because market-based valuation requires complex and costly processes of ascertaining value that adds complexity to the valuation process. Moreover, as observed by Plimmer and McCluskey (2010), market-based assessments ignore the fact that taxpayers may be assetrich but income-poor which can undermine the equity of the system. On the other hand, non-market assessments rely on formulas based on property attributes such as size and location for assessing the property tax payable. Experts advocate for its use where the depth of the property market is thin (Plimmer \& McCluskey, 2010, Franzsen \& McCluskey, 2017a). In practice, Fjeldstad et al. (2017) observe that some countries adopt an area-based approach as a temporary measure.

The tax policy must clearly state whether the tax is to be paid by the owner of the property, the renters or occupiers. The UN-Habitat PT Guide recommends that owners of properties should be taxed if property ownership is well accepted and property rights registration well established in the city. Other occupants/users should be taxed in areas where individual ownership of land is not widely accepted, or where incomplete formal property registration and limited depth of land and property markets are evident (UNHabitat, 2011).

\subsubsection{The Tax Rate}

According to UN-Habitat PT Guide, the principal policy considerations around tax rates are to ascertain first, if the rates are to be set by the local governments (and their agencies) or by higher tiers of government (such as state, regional or federal). According to the UN-Habitat PT Guide, where wider reforms for local government autonomy and accountability are in place, the rate setting should be done locally, but where there is a need to promote tax uniformity and harmonisation throughout the country, then a centralised 
rate setting is appropriate. However, a mixed strategy can be adopted where a central authority is able to establish a range of acceptable rates and the local government is able to select the final rate (UN-Habitat, 2011).

Another consideration in setting an appropriate tax rate is whether all property should be taxed at the same rate, irrespective of the socio-economic status of taxpayers or property use. Collier et al. (2017) note that in many developing countries, different rates are applied to the land and building components and different rates are applied based on property type (residential, commercial or industrial purposes). Variable rates are used for specific purposes such as reducing speculation and supporting housing and real estate development (so only buildings may be charged). However, the UN-Habitat PT Guide recommended a single tax rate for all property types due to its ease of administration, suggesting that the number of rates be kept to a minimum if multiple rates are applied.

\subsubsection{The Cadastre}

A key question is which governmental entity will be responsible for updating the fiscal cadastre. The UN-Habitat PT Guide recommends that local governments should be in charge of updating the cadastre to support decentralisation of governance and autonomy, although it is acknowledged that they may need support from a higher level of government. It is important to note that in reality local governments do not always have complete authority to manage entire property tax systems due to technical, financial and human capacity. Importantly, in recent years, several African countries have launched land information systems to improve the quality of the cadastre and other components of the land administration and management system (Franzsen \& McCluskey, 2017a; McCluskey \& Huang, 2019) often with the support of external organisations. For instance, Uganda was able to launch land information systems with funding from the World Bank (Franzsen \& McCluskey, 2017a). In Ghana, Accra implemented a land information system pilot project from 2000 to 2009 with support from Swedesurvey AB and GeoTech Systems (Jibao, 2017) while The Gambia started its own conversion from paper-based to digital mapping and training in GIS in 2015 (McCluskey \& Jibao, 2017).

\subsubsection{Valuation}

The UN-Habitat PT Guide requires attention to two details: how often will values be updated and who should update values. It recommends updating every one to three years, with indexing between cycles. If local capacity permits, it recommends local authorities update, except for complex properties. It recognises that in practice, however, updating is often carried out by a national or regional agency. There are several challenges associated with the valuation element of property taxation. Detailed information about market-based transfers of properties must be available. In addition, suitable and adequate resources to assess, monitor and update the tax base are required to demonstrate accuracy in assessment. UN-Habitat notes that the method of 
updating should be linked to the legal articulation of the value standard and the administrative capacity of the tax authority. Otherwise, changes in property values would not be captured and tax equity among comparable properties would be lost. While government agencies are known to directly undertake this function (McCluskey \& Franzsen, 2016), UN-Habitat (2011) show that a number of cities outsource the valuation function to private sector partners in whole or in part. However, McCluskey and Franzsen (2016) go on to note that efficiencies have been obscured due to professional charges and lack of quality control. There are also political dynamics that influence the application of true market values to properties.

\subsubsection{Collection}

Tax collection involves sending out tax bills, collecting the taxes and ensuring payment, which are usually local government functions (Bird \& Slack, 2004). Responsibility for collection is intricately woven around the administrative and political structures that underpin property taxation in each city. Thus, it variously falls on local governments, states and federal government agencies. In some cases, the task is outsourced to private sector entities. Effective collection systems operate where there are sufficient resources and expertise to administer property tax and where enforcement is strong. Property tax collection rates in Africa are usually less than $50 \%$ of annual billed amount compared to defaults of only 3-4\% in Japan and the UK, implying defaults of $50 \%$ in Africa, a significant revenue loss (Bird \& Slack, 2004).

The UN-Habitat PT Guide recommends that property collection effectiveness be hinged on incentives that motivate taxpayers to pay, easy and accessible collection processes and fair appeal options that are accessible to taxpayers. Finally, the collection system should also have avenues for discouraging delays and evasion through fair and clearly spelt out penalties such as property seizure (where culturally appropriate), auction and public disclosure. In subsequent sections, we examine the current property tax practice in the four case study cities in the context of these UN-Habitat PT Guide recommendations for effectiveness.

\section{Methodology}

This is a qualitative study based on a case study method. The descriptive case studies lead to the development of a narrative of the phenomena with reference to extant literature (Turnbull et al., 2021). A similar study design has been used in examining property tax in Franzsen and McCluskey (2017a), Goodfellow (2017) and Odimegwu et al. (2018). We choose four cases (Addis Ababa, Dar es Salaam, Kigali and Lagos). Each case is the most important city in its country (all are capital cities, apart from Lagos, which is the most commercialised and industrialised city in Nigeria). Each city has a different property tax system, allowing a study of several dimensions of property taxation from which we draw an understanding of the challenges, gaps and prospects for property tax in Africa. The selection of cases is therefore in line with the description of a case by Gerring (2007). The use of multiple cases in 
this study helps in the identification of commonalities (and differences), which strengthens the understanding of the property taxation system in Africa and provides a strong impetus for other researchers to develop emerging theories from findings. The material used for analysing each case is obtained from published sources, both research and policy papers.

\section{Case Studies}

The review of each city in this section is presented according to the five elements identified in the UN-Habitat PT Guide as shown in Table 1. Each city case is preceded by a narrative that shows the context within which the property tax sector operates, followed by the analysis of its practises in defining the property tax base, setting the rate, maintaining the fiscal cadastre, updating the values and collecting. We subsequently analyse peculiarities, similarities and differences in tax administration that could offer insights into the effectiveness of each study city. 
Journal of African Real Estate Research

Special Issue: Women in African Real Estate and Urban Development Research

Table 1: Adaptation of the Tax Revenue Identity Perspective of UN-Habitat to the Case Study Cities

\begin{tabular}{|c|c|c|c|c|c|}
\hline \multirow{2}{*}{$\begin{array}{l}\text { Property Tax } \\
\text { Element }\end{array}$} & \multirow{2}{*}{$\begin{array}{l}\text { UN-Habitat PT Guide's Core } \\
\text { Questions }\end{array}$} & \multicolumn{4}{|c|}{ Current Practice in Case Study Cities } \\
\hline & & Addis Ababa & Dar e Salaam & Kigali & Lagos \\
\hline \multicolumn{6}{|l|}{ Policy Elements } \\
\hline \multirow{3}{*}{ Defining the Base } & $\begin{array}{l}\text { Will the base include land only, } \\
\text { immovable improvements only or } \\
\text { both? }\end{array}$ & Buildings Only & Buildings Only & $\begin{array}{l}\text { Buildings and Land } \\
\text { Separately }\end{array}$ & $\begin{array}{l}\text { Buildings with Land } \\
\text { Inclusive }\end{array}$ \\
\hline & $\begin{array}{l}\text { Will the value of the tax base be } \\
\text { linked to capital, market value or } \\
\text { property attributes? }\end{array}$ & Annual Rental Value & Market Value & $\begin{array}{l}\text { Buildings: Market Value } \\
\text { of Building; Land: } \\
\text { Surface Value of a Plot of } \\
\text { Land }\end{array}$ & Capital Value \\
\hline & $\begin{array}{l}\text { Will land owners or occupants be } \\
\text { responsible for paying the tax? }\end{array}$ & Property Owner & Property Owner & Property Owner & Property Owner \\
\hline \multirow[b]{2}{*}{$\begin{array}{l}\text { Setting the Tax } \\
\text { Rate }\end{array}$} & $\begin{array}{l}\text { Will tax rates be set locally or } \\
\text { centrally? }\end{array}$ & Federal Government & Federal Government & Federal Government & Federal Government \\
\hline & $\begin{array}{l}\text { Will there be a single tax rate or } \\
\text { multiple rates for different types } \\
\text { of property? }\end{array}$ & $\begin{array}{l}\text { Single tax based on range } \\
\text { of } 1 \% \text { to } 4.5 \% .\end{array}$ & $\begin{array}{l}\text { Flat rates specified by } \\
\text { law. }\end{array}$ & $\begin{array}{l}\text { Multiple rates according } \\
\text { to building use: } 1 \% \text { for } \\
\text { residential buildings; } \\
0.5 \% \text { for commercial } \\
\text { buildings; and } 0.1 \% \text { for } \\
\text { industrial and other } \\
\text { buildings. }\end{array}$ & $\begin{array}{l}\text { Multiple rates according } \\
\text { to building use and } \\
\text { ownership type: } 0.0394 \% \\
\text { for owner-occupied } \\
\text { residential property, } \\
\text { residential property } \\
\text { without owner in } \\
\text { residence, commercial } \\
\text { property used by the } \\
\text { occupier for business } \\
\text { purposes and open empty } \\
\text { land; } 0.132 \% \text { for } \\
\text { industrial premises of } \\
\text { manufacturing concerns; } \\
0.132 \% \text { for residential } \\
\text { property/private school } \\
\text { (owner and third party). }\end{array}$ \\
\hline
\end{tabular}


Journal of African Real Estate Research

Special Issue: Women in African Real Estate and Urban Development Research

\begin{tabular}{|c|c|c|c|c|c|}
\hline \multicolumn{6}{|c|}{ Administrative Elements } \\
\hline $\begin{array}{l}\text { Managing the } \\
\text { Fiscal Cadastre }\end{array}$ & $\begin{array}{l}\text { Which governmental entity will } \\
\text { be responsible to update fiscal } \\
\text { cadastre? }\end{array}$ & Local Government & Local Government & Federal Government & State Government \\
\hline $\begin{array}{l}\text { Updating } \\
\text { Taxable Values }\end{array}$ & $\begin{array}{l}\text { Who bears responsibility for } \\
\text { value updates and how often will } \\
\text { values be updated? }\end{array}$ & $\begin{array}{l}\text { Local Government or } \\
\text { Sub-city Government }\end{array}$ & Local Government & Federal Government & State Government \\
\hline \multirow[t]{2}{*}{ Collection } & $\begin{array}{l}\text { What incentives do taxpayers } \\
\text { have to pay the tax? }\end{array}$ & Hand delivery & $\begin{array}{c}\text { Partly outsourced } \\
\text { services; Digitalised } \\
\text { payment and tracking } \\
\text { systems; No strict } \\
\text { enforcement of penalties. }\end{array}$ & $\begin{array}{c}\text { E-payments systems; } \\
\text { Celebration of taxpayers } \\
\text { day. }\end{array}$ & $\begin{array}{l}\text { Instalment payment; } \\
\text { Multiple payment } \\
\text { channels; Discounts for } \\
\text { early payments. }\end{array}$ \\
\hline & $\begin{array}{l}\text { What sanctions will be used for } \\
\text { non-payment? }\end{array}$ & Reports of tax evasion & $\begin{array}{l}\text { Restrain goods; Forfeiture } \\
\text { of property; } \\
\text { Imprisonment. }\end{array}$ & $\begin{array}{l}\text { Strictly enforced penalties } \\
\text { for default. }\end{array}$ & $\begin{array}{l}\text { Penalties for late } \\
\text { payment. }\end{array}$ \\
\hline
\end{tabular}




\subsection{Addis Ababa, Ethiopia}

\subsubsection{Context}

Ethiopia operates with a system of ethnic federalism whereby the country is divided into nine federal states and two separately administered cities, Addis Ababa and Dire Dawa (Goodfellow, 2017). Unlike other cities in the regional state, Addis Ababa collects its own taxes. Land is nationalised in Ethiopia, so both urban and rural land are under public ownership. This underpins the property tax system, influencing the choice of tax base and tax rate.

In the past, Ethiopia operated a single revenue instrument based on the combined value of land and buildings, but this no longer exists (Goodfellow, 2015). When land was nationalised in 1974, a new law split property tax into two components: a roof tax and a land rent. The roof tax is acknowledged as closer to being a property tax (Goodfellow, 2015) and is the focus of this section.

\subsubsection{Tax Base}

Addis Ababa, like all Ethiopian cities, has a municipal tax known as a 'roof tax' or 'city house tax'. According to the Urban Land Rent and Urban Houses Tax Proclamation No 80/1976, the tax is levied as a percentage of the annual rental value of the house (Franzsen \& McCluskey, 2017b).

\subsubsection{Tax Rate}

The roof tax is based on assessment of annual rental value, with rates ranging from $1 \%$ to $4.5 \%$ (Franzsen \& McCluskey, 2017b; Goodfellow, 2017). The rates are progressive, increasing as the property value increases. In accordance with the property law of Ethiopia, property owners are liable for the tax, not renters (Soressa \& Gebreslus, 2009). Rates are set centrally in accordance with the national property tax proclamation but usually after discussions with the local governments (Franzsen \& McCluskey, 2017b).

\subsubsection{Coverage}

When the Ethiopian People's Revolutionary Democratic Front (EPRDF) took power in 1991, it took actions to address the incomplete property valuation rolls used for property taxation (Goodfellow, 2015). In 1996, a census of all properties was carried out. Since then, there have been no updates of the property roll in the city. The current cadastre therefore excludes new highrise commercial developments and more than 100,000 condominium apartments built by the State in recent years (Goodfellow, 2017). Almost half $(45 \%)$ of all structures are not on the roll in Addis Ababa (Franzsen \& McCluskey, 2017b).

While the UN-Habitat PT Guide suggests that administrative capacity may be a cause for not achieving significant coverage, political factors can be more 
important, as Goodfellow (2017) argues is the case for Addis Ababa. He contends that fear of political repercussions from a powerful middle class combined with powerful, wealthy, property owning diaspora-returnees have influenced low coverage and enforcement of property tax payment.

\subsubsection{Valuation}

The 1996 census of properties in Addis Ababa was carried out using computerised systems and identification and valuation of both formal and informal structures. This led to a new tax bill that dictated a fourfold increase in taxable rates, much to public outcry. In response, the government slashed the rates by one quarter. Since then, there has been no revaluation of properties or audit of new ones despite a rise in real estate development in the city. This has resulted in a significant loss of revenue because property values have not been updated for 25 years, contrary to the 1-3-year benchmark recommended in the UN-Habitat PT Guide. In addition, Goodfellow (2017) reports that a 2006 study comparing bank valuations with property values on government rolls showed a disparity of more than $300 \%$. These remarkable differences are an indication of the revenues that have been lost due to lack of updated rolls.

Goodfellow (2017) argues that the unwillingness to raise roof taxes in the capital city is historically rooted in political rather than administrative factors, citing the example of other regional governments in Ethiopia that have used their devolved powers to substantially increase roof tax rates over the years.

\subsubsection{Collection}

City and sub-city governments are responsible for tax collection (Goodfellow, 2017). The city administration is legally allowed to send tax billing notifications to the taxpayers through registered mail or in person, although hand delivery is the norm due to lack of proper street signage (Soressa \& Gebreslus, 2009). Further, payment of property taxes on new properties is voluntary because they are not officially captured by the city government. It is not surprising that as of 2014, the roof tax contributed just $0.1 \%$ of total city revenue (Goodfellow, 2017). This supports Soressa and Gebreslus' (2009) observation that the lack of drive for enforcement has resulted in failure of the urban local governments to identify tax defaulters and serve notices.

\subsection{Dar es Salaam, Tanzania}

\subsubsection{Context}

The administration of property tax in Tanzania has changed several times since 2008, before which local governments had often outsourced their property tax collection responsibilities with varying level of success. In 2008, the collection of property tax was centralised. A national agency, the Tanzania Revenue Authority (TRA), was assigned the task of collecting 
property taxes on behalf of municipalities in Dar es Salaam with the objective of improving revenue collection. Due to political exigencies, by February 2014, the federal government returned the responsibilities back to the local governments, only to centralise the process again in July 2016 in a bid to ensure probity and sustain the high performance experienced when TRA was in charge. This became necessary due to the lack of efficiency in tax base coverage and revenue collection levels of the three local government authorities in Dar es Salaam (Kayuza, 2014). However, a lack of cooperation between the municipalities and the TRA reduced the latter's performance because local government officials were reluctant to carry out value updates as they no longer had responsibilities for collecting tax. Thus, the performance of TRA, which had achieved remarkable progress in terms of increased collection rates due to innovative payment options, was not sustained.

\subsubsection{Tax Base}

In Dar es Salaam, property tax is levied based on value of buildings and improvements within the taxing jurisdictions, and so excludes undeveloped land. The legal duty to pay property tax is imposed on the property owner (Massawe, 2020). The TRA has been successful in using a digitalised system to identify properties and has some expertise in valuing buildings, which fits with the UN-Habitat's recommendation.

\subsubsection{Tax Rate}

Flat rates are chargeable according to law. A study by Namangaya (2018) revealed that in the most recent phase of centralisation, the TRA ignored the valuation rolls supplied by the local governments due to their being incomplete, and instead charges a minimal flat rate. Slightly different rates are levied for multi-storey versus 'ordinary' (single-storey) buildings. The limitation of the flat rate is that it misses revenue from increased property values and can also enhance unfair practices by the property owner.

\subsubsection{Coverage}

The local government is responsible for registration of buildings. Between 1993 and 1999, Dar es Salaam enjoyed critical interventions in the development of a GIS platform to aid tax collection under the Urban Sector Engineering Project (USEP) of the World Bank and the Norwegian Development Agency. The objective of the project was to adopt the use of aerial photography to capture buildings and develop spatial building databases linked to valuation rolls. Although it greatly enhanced the coverage of the tax base, there are some concerns, including gaps in technical data, many houses being left out, inaccurate valuation data, inaccurate locations and lack of updating the database (Namangaya, 2018). Moreover, the data system of the internal revenue sections and that of property-based departments were not linked. This is a critical link that Namangaya (2018) and the UN-Habitat PT Guide recognise as key for effectively identifying new properties and their owners and determining tax liability. 


\subsubsection{Valuation}

The valuation department in the local government is responsible for the preparation of the valuation roll and issuance of the tax demand notices (Massawe, 2020). Thus, TRA depends on information from local government offices to develop property registers. The local governments are, however, not motivated to provide these services because of their grievance at being dispossessed of their tax collection responsibilities by the TRA (Fjeldstad et al., 2009; Fjeldstad et al., 2019). This has reduced the effectiveness of the system in areas such as such as linking compliance with improved local services and developing comprehensive and detailed property registers.

\subsubsection{Collection}

During the period of the first centralisation in 2008, the TRA was able to marshal resources to implement reforms in collection processes, including the introduction of digitisation and non-cash payment regimes and outsourcing the valuation function (in whole or part) to private sector partners. This increased the tax revenue substantially, more than tripling the number of eligible taxpayers from 31,160 to 104,629 . TRA expanded satellite imaging of taxpayers' property, introduced electronic payment and tracking systems and increased the profile of properties to expand access. Interference by local political elites who lobbied to pay less or no tax was thwarted by the introduction of a centralised system based on electronic payment systems that are non-discriminatory (Fjestald et al., 2019). Compliance is enhanced by empowering the collection agency to restrain goods, seize rents and profits, fine and charge interest exceeding the commercial rate on late payments, seize property and even imprison the evader (Massawe, 2020). However, the ability of these provisions to serve as deterrents to default in payment and tax evasion are only as good as the strength of enforcement, which is judged to be low (Namangaya, 2018).

\subsection{Kigali, Rwanda}

\subsubsection{Context}

In Rwanda, the state has supreme power over all the land. Land owners receive a renewable emphyteutic lease contract. A decentralisation policy was introduced by the Rwandan Patriotic Front (RPF) in 2000 that devolved the administration of property tax to local governments with the expectation that it would be their major source of locally generated revenue. Between 2006 and 2013, Rwanda's compound annual growth rate of construction was relatively high at $19.7 \%$ because the government incentivised investment in construction and real estate. Franzsen and Youngman (2009) reported that as of 2009, experts predicted that property taxation could generate revenues equivalent to 5\% of Rwanda's GDP. Yet in 2013, the property tax collected nationally (the vast majority from Kigali) was just $0.018 \%$ of GDP. The central government's Rwandan Revenue Authority (RRA) took over property tax collection from the districts in 2014 to improve efficiency. Further 
reforms were made with the 2018 Immovable Property Tax Law, which increased and harmonised tax rates for property (land and buildings) and made tax on rental income more progressive. Chemouni (2020) reports that the personal intervention of the Rwandan president was a major factor in the introduction of the new tax overcoming stiff resistance to reforms by elitist, property owning politicians. Despite this, Chemouni cautions that an inherent reluctance to tax property has been identified as one of the weakness of the RRA, despite its being one of the best performing organisations in the country. Goodfellow (2017) explains that this reluctance is due to the influence of the political elite, citing how they truncated tax reforms attempts in 2011 .

\subsubsection{Tax Base}

Kigali levies a tax on buildings and another on land. Taxes are linked to the market value of a building and improvements and land lot area. The 2018 Immovable Property Tax obligates the owner, usufructuary or any other person considered to be the owner. The drive for efficiency by the RRA, which employs private sector practices, suggests that they would be able to gather the technical capacity for identification of buildings for valuation purposes as the UN-Habitat PT Guide recommends.

\subsubsection{Tax Rate}

The 2018 Immovable Property Law provides tax rates for land and buildings with an incremental increase component over a period of five years (Rwandan Revenue Authority, 2018). Rates have been increased to 1\% of the market value for residential buildings, $0.5 \%$ for commercial and $0.1 \%$ for industrial and other buildings. Property values are determined as either the acquisition value of buildings purchased on open markets, value as determined by a certified valuer or value as determined by the computerised system (Rwandan Revenue Authority, 2018). Thus, Kigali has migrated from the recommended single rate suitable for administrative ease to multiple rates that could capture property values from various categories of properties. The capacity of RRA to increase revenues from these multiple rates remains to be seen.

\subsubsection{Coverage}

Kigali has benefitted from a land tenure regularisation process under the Rwanda Natural Resources Authority (RNRA) that enabled the demarcation, adjudication and digitisation of 8.4 million titles, $90 \%$ of which were collected by property owners in Kigali (Franzsen \& McCluskey, 2017b). The exercise, which began in 2008, was completed across the entire country in 2015 (Uwayezu \& de Vries, 2020). The process was the responsibility of the Lands and Mapping Department within the RNRA and has been critical in identification of taxable properties (Franzsen \& McCluskey, 2017b). 


\subsubsection{Valuation}

Self-reporting of property value had previously been introduced as a strategy to check the administrative burden of developing valuation rolls. However, Goodfellow (2017) links this to low tax revenue generation because selfreporting provides massive opportunities for deliberate undervaluation. This opportunity is exacerbated by the lack of provisions guiding how property owners should obtain these values.

The 2018 law provides that property taxes remain the same for 5 years unless there is a major change in the property to the extent that its loses or gains $20 \%$ of its value. This is in line with the recommendation of value updates within 1-3 years in the policy brief.

\subsubsection{Collection}

An annual Taxpayer Appreciation Day is celebrated to recognise best performing taxpayers. Further, taxpayers have various options for remitting their payments, such as through Mobile Money, Infinity, Mobicash, Ebanking, E-payment or at any commercial bank (Rwandan Revenue Authority, 2018). Anecdotal accounts from Chemouni (2020) show that taxpayers are careful not to delay payment due to the stiff penalties.

\subsection{Lagos, Nigeria}

\subsubsection{Context}

Nigeria is one of the few countries that operate a decentralised property tax system, having devolved to the state and local governments. Thus, the country is made up of a multiplicity of tax systems and jurisdictions as each of its 36 states makes its own laws (Aniyie, 2017; Odimegwu et al., 2018). Lagos is the acknowledged commercial and economic capital of Nigeria and provided leadership in generating internal revenue through property tax at a time the nation was coming out of decades of military misrule, with attendant political and financial stagnation (Fjestald et al., 2019). In 2001, Lagos passed its Land Use Charge Law (LUCL), which consolidated three existing property-based taxes (neighbourhood Improvement tax, tenement rates and ground rents) into a single tax. Babawale \& Nubi (2011), reported the LUCL enjoyed only limited acceptability as expressed in calls for its withdrawal by stakeholders such as the Nigerian Institution of Estate Surveyors and Valuers, Nigerian Bar Association, Chartered Institute of Taxation of Nigeria, property owners and the business community. As a result of litigation and public agitation against opaque provisions for rate setting, penalties, tax liability and other issues, tax bills for 2001 were waived and massive discounts of up to $75 \%$ initiated to solicit compliance (Babawale \& Nubi, 2011). However, the land use charge has been reported as an example of a success story in terms of revenue generation, with Collier at al. (2017) and Fjestald et al. (2019) attributing this success to the personal leadership of two successive governors of Lagos. 
In 2018, a new land use charge law was enacted but, surprisingly, it retained most of the provisions that had brought public discomfit while also announcing increased rates, again to much public outcry by stakeholders. A new 2020 land use charge law was recently announced to repeal the 2018 Law. It reversed the land use charge to pre-2018 provisions and reduced some rates, but upheld the 2018 method of valuation. According to the Government, these reforms were made in response to the agitations of Lagosians to reduce the exorbitant rates of the 2018 law (Lagos State Government, 2020).

\subsubsection{Tax Base}

The land use charge is levied on the capital value of land with improvements. It uses an area appraisal model developed from a statutory formula (Babawale $\&$ Nubi, 2011). Ezomike and Isiadinso (2018), citing the now revoked 2018 law, note that the owner or the occupier of a property is liable for the tax if the lease term is less than 10 years. Where the lease is longer than 10 years, the owner is liable for payment. The law does not specify who is responsible if the lease term equals 10 years. However, a general provision of the LUCL that has survived through several revisions is that while the owner of the property is liable, any occupier may be declared as an agent, thus becoming liable to pay the charge. Such agent is expected to make the payments from monies due to the owner. This is another contentious aspect of the Lagos LUCL since inception because of the lack of state-wide records on property transactions and ownership in the city.

\subsubsection{Tax Rate}

Tax rates are set by the state government through the enabling law. The most recent law (2020 New Land Use Charge Law), introduced a 48\% reduction in the annual charge rates. The rates vary by property type as listed in Table 1 (Akosile, 2020; Lagos State Government, 2020). It is notable that the rates for residential properties differ according to use and tenure, with owneroccupied properties charged the lowest and properties that are fully tenanted paying higher rates. However, the law introduced an ambiguous declaration for residential/private school. It is not unclear why these two building use types were lumped together, and this will certainly create difficulties for tax payers. Lagos utilises multiple rates, yet the ability to ascertain the accurate property type is limited by the depth of the real estate market and limited technical capacity to track changes in property use in the city of more than 20 million people. This creates a potentially difficult case for property tax effectiveness.

\subsubsection{Coverage}

Lagos was the first city to attempt to use GIS in property taxation in Nigeria, which produced a comprehensive digital map that contained the details of the land parcels and building areas in Lagos. Over a period of three years, Lagos recorded a 14-fold increase in the number of enumerated properties from 
45,000 in 2007 to 635,000 in 2010 (Goodfellow, 2017). There were limitations however, as field enumerators had to undertake physical inspection to collect physical characteristics and unique attributes of each property. Thus, Lagos could not rely on an error free valuation roll.

\subsubsection{Valuation}

The 2001 LUCL provides that land value and building value rates are to be reviewed at least once every five years on the basis of value updates from professional valuers and consultants. The Commissioner for Finance is empowered to carry out periodic reviews of the value rates in comparison with the rate of inflation. However, the law did not specify how the professional valuers and consultants are to be held accountable; neither does it provide for questioning the basis of valuation or the basis for determining the proposed inflationary adjustments (Babawale \& Nubi, 2011; Ezomike \& Isiadinso, 2018). These shortcomings remain in the 2020 law. Thus, although the practice of updating values aligns with the recommendations of the UNHabitat PT Guide for periodic updates and indexing in a 1-3-year period, lack of accountability and transparency to the taxpayers could affect compliance.

\subsubsection{Collection}

While the local government authority is authorised to collect property tax by the Nigerian Constitution, the 2001 LUCL provision for the 'devolvement' of this function to the state government has been retained in the new law. The Lagos State Government outsources collection to private sector agents, however Babawale and Nubi (2011) criticise this practice for lack of transparency and accountability to the public on revenues collected. Reflecting best practices in collection recommended by the UN-Habitat PT Guide, e-payment systems have eased the collection processes and discounts of $25 \%$ are offered for early payment before the due date (Lagos State Government, 2020). The law clearly spelt out penalties against evasion and delays, but the government has recently announced a waiver of penalties for 2017, 2018 and 2019. This could lead to increased revenue from property tax in the city.

\section{Discussion}

Clear areas of commonality are visible in the policy and practice of property taxation in the cities under review despite their having distinct systems based on their political and socio-economic frameworks. Each city has defined strategies within the tax policy elements with specified criteria for defining the tax base and settling the tax rate, and the tax administrative elements of maintaining the fiscal cadastre, valuation and collection, some of which have worked and others of which have failed. There are also challenges such as political interference that work against the system or have come to define the system with interesting outcomes. These are examined in turn. 
For effective design of a property tax base, researchers such as Franzsen and McCluskey (2017b) opine that the tax base for property taxation should reflect the maturity of the property market. The UN-Habitat PT Guide adds that the administrative and technical capacities must be in place for adopting more complex practices such as levying buildings and linking the base to market values. All the cities in the study levy buildings, either alone or in addition to land. Lagos is the only city that levies both land and building in the same tax while Kigali charges a building tax separate from a land tax and Addis Ababa charges a building tax separately from a land rent. The concern about lack of capacity to identify and value buildings is most visible in Addis Ababa, which is distinct in the severe undervaluation of its taxable properties stock.

Similarly, while previous research recommends the use of the non-value area basis as a first step towards a market-based assessment basis, all the cities linked the tax base to a value component, which requires administrative, technical and financial resources to update. All the cities also levy property owners with the general assumption that they stand to benefit from the rents arising from their properties either directly (when it is let), or indirectly, when it is owner-occupied.

Setting the tax rate is a critical property tax revenue element. It is also fraught with political interference. Dar es Salaam, Addis Ababa and Kigali are similar in having tax rates set by the federal government by law. Lagos is the only city in the study where the state government sets its rates, reflecting the devolution of property tax from the federal Nigerian government. Thus, responsibility for tax setting depends on the political context of the country. On the other hand, Lagos and Kigali are similar in setting multiple rates for different categories of property use. This can potentially undermine effectiveness if the recommendation of the UN-Habitat PT Guide for administrative and technical sophistication in identifying and levying properties is not in place. Kigali's rates were announced in 2018; there is as yet little literature to assess their performance. The dependence on flat rates in Dar es Salaam and Addis Ababa also has implications. Although the simplicity and administrative ease is advantageous for effectiveness, as emphasised by the UN-Habitat PT Guide, the flat rate approach does not optimise revenues as it fails to capture the true market value of properties.

There is evidence of political interference in rate setting, however, across all cases. In Kigali the influence of a politically strong, elite property- owning class has been instrumental in delaying increases in rates while in Addis Ababa the delays have been made to placate powerful, middle income groups who own properties within the city. In his analysis of Kigali and Addis Ababa, Goodfellow (2017) had predicted that political interests would continue to impede the ability to increase rates in Kigali. Interestingly, these political interests have been checked by the personal intervention of the president as Chemouni (2020) shows. The 2018 Immovable Property Tax Law reforms have made tax on rental income more progressive. The performance of the law will be instrumental to increasing Kigali's property tax to GDP ratio 
going forward. The success of the 2001 land use charge in Lagos was due to the personal leadership of two successive governors (Collier et al., 2017; Fjestald et al., 2019). While the issue of powerful, autocratic leaders versus democratic governance and political clientelism in African politics is a subject of much interest, in-depth discussion of these is not within the scope of this paper. However, the examples of Kigali and Lagos show the potential for enacting bold and far-reaching reforms if a powerful leader supports and resonates with the oft-cited 'political will' critical for addressing some of urban Africa's seemingly intractable problems.

Academic researchers (Babawale \& Nubi, 2011; Namangaya, 2018; Balogun, 2019; McCluskey \& Huang, 2019) agree that there is value in using an information and communications technology (ICT) system to manage the fiscal cadastre. GIS have been used successfully in all four cities, at various scales to identify properties and increase the number of properties captured in the cadastre. However, the use of GIS for property taxation thrives when there is a linkage between the cadastre and other city business data, as Namangaya (2018) argues and as recommended by the UN-Habitat PT Guide. It is also important to note the financial cost, time and technical manpower that are required to set up the system. The literature shows that African countries that utilise GIS, such as Tanzania, have been supported by foreign funding. Where the property tax administration function is not domiciled in one cadre of government, there is also need for co-operation. Again, Dar es Salaam is a good example of how lack of inter-governmental co-operation undermines efficiency.

For property tax to be effective, property values need to be periodically updated to ensure the tax is reflective of the current tax base. The UN-Habitat PT Guide recommends a periodic review every 1-3 years, with indexing in between. Addis Ababa has not updated values since 1996, which creates significant revenue loss. Lagos and Kigali have incorporated value updates into their laws, albeit in different ways. While Lagos allows for value increases every five years, it also provides that the Commissioner for Finance can increase the rates in line with inflation. However, the law did not provide guidelines for how this is to be implemented. The law in Kigali requires percentage increases for five years. The implementation of these provisions will no doubt increase revenue generated from property taxation in Lagos and Kigali over time although taxpayer education will be required to ensure compliance.

One area of differentiation across the cities is who is responsible for updating values. The UN-Habitat PT Guide recommends this task be handled by local governments while acknowledging that they may need the support of higher tiers of government. In Ethiopia and Tanzania (Addis Ababa and Dar es Salaam), updating of values is vested with the local governments while in Rwanda, it is a federal function. Lagos state is firmly in control of valuation updating in line with the federation structure of Nigeria. 
The literature shows that lack of effective collection has been the bane of property tax revenue generation in Africa. Cumulative arrears contribute to inefficiencies that require the adoption of 'collection-led' rather than 'valuation-pushed' reforms to tackle due to current low collection rates and high default rates (McCluskey \& Franzsen, 2016; Fjestald \& Goodfellow, 2017). However, a push towards collection reforms might create some inequities, for instance where the focus is on collecting from the poor and unheard who are easy targets and do not wield the political power of the elites who often utilise their powerful political base to thwart attempts at taxing their real estate directly, as reported for Dar es Salaam in Fjestald et al. (2019). This might explain why the UN-Habitat PT Guide recommendation for increasing collection efficiency promotes making the process easy and accessible for taxpayers and enforcing penalties for non-payment. There has been a focus on collection reforms in Dar es Salaam, Lagos and Kigali through outsourcing services to the private sector and introducing more accessible payment platforms.

The use of private tax consultants to collect payments rather than local council employees in Dar es Salaam and the use of Ministry of Finance staff in Lagos has helped to stem corrupt practices and improved efficiency in both cities. However, their use in collection and enforcement in Lagos has been criticised because the law did not specify how they are to be held accountable. Lagos, Dar es Salaam and Kigali have identified non-physical payment platforms such as electronic systems offered by commercial banks for taxpayers to use from the convenience of their homes with their mobiles. These are in consonance with best practices for collection effectiveness detailed in the UN-Habitat PT Guide. Collection reforms therefore help in improving efficiencies and should be incorporated into property tax administration.

\section{Conclusion}

This study has explored property tax administration in cities in East and West Africa. Each city's system of property taxation has unique attributes, yet a quest for optimising revenues remains a common aspiration. As each city continuously seeks improvements, they have navigated several reforms, some successfully, and others not. Their experiences provide lessons for implementing system wide and specific component reforms that would be useful for rapidly growing African cities.

Efficiency driven reforms are a factor in successfully improving property tax administration systems. Such reforms are often undertaken as a part of a national land reform or local government finance reform, or as a response to the need to raise revenue. Tanzania recentralised its property tax operations in 2016 in a bid to ensure accountability and increase revenues. Rwanda's recent reform has addressed factors that reduced revenue generation from its property tax sector. Dar es Salaam and Kigali will both benefit from higher property tax revenues if these reforms are properly implemented. When Lagos merged three property related taxes into one, it was seen as a laudable, 
ambitious project that eventually raised the internally generated revenue of the city significantly. Cities like Addis Ababa that have not made any changes in their property tax policy and administration processes can benefit if core aspects of their tax policies are reviewed. However, system wide reforms must be carried out within a framework of political stability and intragovernmental co-operation that permits information sharing and seamless alignments between the property tax sector and other governmental processes. As the case of Dar es Salaam shows, this is even more crucial if responsibility for various parts of the property tax system is distributed among different agencies.

Literature shows the challenges that might confound centralised systems where the federal government, through its tax agency, has overarching responsibilities for property tax policy and administration, yet depends on others for vital information. The Tanzanian experience presents an example. Although Tanzania's first step towards centralisation of property tax yielded higher collection rates, sustainability was limited due to lack of co-operation from the local governments, who were still required to carry out important processes such as updating the cadastre. Thus, centralised systems may suffer where the anchor agency has no direct access to local information on the property tax base to develop property registers. In contrast, decentralised systems are able to access local information to develop property tax registers and may be better able to connect property tax compliance with local services, which can motivate greater compliance and voluntary payment. It is therefore important that mechanisms are in place where separate agencies are in charge of elements of the property tax to harmonise their databases, and structures are in place to enhance co-operation, such as revenue sharing. In addition, a critical step to improve intra-governmental cooperation is to link all basic revenue administrative components of property tax (maintenance of property registers, billing and enforcement) with other revenue sources such as business (permits, house rents, land rents and user charges, water and electricity). Access to this combined database would be beneficial to all agencies and potentially provide additional motivation for intragovernmental cooperation.

An efficient property tax system will enable African cities tap into the revenues from current and future investments in their real estate markets. What is required therefore is to ensure that the potential tax revenues from new commercial and residential developments are captured. This calls for a systematic linkage between real estate investment and property taxation in a manner that also links other government agencies such as the planning offices (that issue development permits) so as to capture new developments. A land information system would serve this purpose. Technology-driven reforms for tax base identification, updating the cadastre, collection and monitoring compliance have been very effective in cities such as Kigali, Lagos and Dar es Salaam. Technology offers both short-term wins (such as e-payment platforms) and long-term benefits (such as GIS enabled fiscal cadastre) to support property taxation and can be explored in various city contexts. 
The political economy system that dictates how the functional tiers of government interact represents a far more potent threat to the generation and use of property tax revenues for urban improvement than property tax administration. Power structures within government and struggles between a constitutionally recognised local government and a dominant tier of government (such as state government) create issues. Such struggles exist between the federal government and the cities in Tanzania and Rwanda and the state and city governments in Lagos. Property tax is the most visible (and often viable) means of local revenue generation in other parts of the world; however, in Africa, the property tax functionality of local governments has been relegated by the tiers of government meant to support them. Dar es Salaam and Lagos have suffered from lack of technical and financial capacity. Lagos has been politically dominated by a very strong higher tier of government. Nevertheless, local governments represent the level of governance where local problems are identifiable through community involvement. There is a need to strengthen their human resources and their financial, governance and technical capacity to perform functions such as updating the cadastre and monitoring compliance. The RRA's adoption of private sector ethos in operating as a quasi-public organisation has improved staff capacities. A similar approach of retraining and reorientation at the local government level could trigger efficiencies in the property tax sector.

Importantly, while a review of the property tax administration systems in the case studies has generated a better understanding of the dynamics shaping property tax revenues and identified some strategies to overcome recurring challenges, new questions have also emerged. One of these is the role of local interest groups such as property owners, professional bodies and industry in policy formulation and administration. Public dissatisfaction after the announcement of changes in property tax components in Lagos and Addis Ababa were evident. However, there has been little discourse on how these groups should be engaged in the steps of property tax policy making and implementation. Secondly, there is the question of how tax revenues are used to provide community-based infrastructure. This links to the need for improved stakeholder participation. Addressing these issues would strengthen compliance and potentially increase the sustainability of successful reforms.

In the final analysis, an evaluation of the property tax systems of four African cities indicates that reforms have been undertaken that have improved performance to a varying extent in recent years. The conversation on how to continually improve is still relevant for both academic research and policy processes. Thus, property taxation is not yet an optimised driver for revenue generation for more liveable cities in Africa.

\section{References}

African Development Bank. (2018). African Economic Outlook (AEO) 2018. Abidjan, Côte d'Ivoire: African Development Bank. [Online]. 
Available at: https://www.afdb.org/en/documents/document/africaneconomic-outlook-aoe-2018-99877. Accessed: 31 ${ }^{\text {st }}$ May, 2021.

Ahmad, E., Brosio, G. \& Poschl, C. (2014). Local property taxation and benefits in developing countries-overcoming political resistance. Asia Research Centre Working Paper 65. [Online]. Available at: https://www.semanticscholar.org/paper/Local-property-taxation-andbenefits-in-developing-

AhmadBrosio/aef19e88f1144f1a59a61887fe9aae62465ba28a.

Accessed: $9^{\text {th }}$ November, 2020.

Akosile, G. (2020). Speech delivered by the Honourable Commissioner for Finance at a press briefing on the $2020 \mathrm{New}$ Land Use Charge Law. [Online]. Available at:

https://twitter.com/gboyegaakosile/status/1291305228877406213. Accessed: $30^{\text {th }}$ May, 2021.

Amin, K., McCluskey, W.J. \& Franzsen, R. (2017). Egypt. In Franzsen, R \& McCluskey, W. (Eds), Property Tax in Africa: Status, Challenges and Prospects. Cambridge, MA : Lincoln Institute of Land Policy, pp.170183.

Aniyie, I. (2017). Recognition of the rights of taxpayers and its implications, ATRN working paper 02. African Tax Administration Forum. [Online]. Available at:

https://papers.ssrn.com/sol3/papers.cfm?abstract_id=3034670.

Accessed: $13^{\text {th }}$ November, 2020.

Babawale, G. \& Nubi, T. (2011). Property Tax reform: an evaluation of Lagos State Land Use Charge, 2001. International Journal of Law and Management, 53(2), pp.129-148.

DOI: $10.1108 / 17542431111119405$.

Balogun, T.F. (2019). Development and implementation of GIS-based property tax management system for Benin City, Nigeria. African Journal of Land Policy and Geospatial Sciences, 2(3), pp.97-112.

Bird, R.M. \& Slack, E. (2004). Land and Property Taxation in 25 Countries: A Comparative Review. CESifo DICE Report. [Online]. Available at: https://doi.org/10.4337/9781845421434.00007. Accessed: $24^{\text {th }}$ March, 2021.

Chemouni, B. (2020). Revenue Extraction Is Not Enough: The Ambiguous Effectiveness of the Rwandan Revenue Authority. ESID Working Paper No 157. [Online]. Available at:

https://papers.ssrn.com/sol3/papers.cfm?abstract_id=3716821.

Accessed: 24 ${ }^{\text {th }}$ March, 2021.

Collier, P., Glaeser, E., Venables, T., Manwaring, P. \& Blake, M. (2017). Land and Property Taxes: Exploiting Untapped Municipal Revenues. IGC Cities that Work Policy Brief. [Online]. Available at: https://www.theigc.org/wp-content/uploads/2017/08/Land-andproperty-taxes-policy-brief updated.pdf. Accessed: $18^{\text {th }}$ March, 2021.

Ezomike, C. \& Isiadinso, O. (2018). Property Taxation in Lagos State: A Review of the Lagos State Land Use Charge Law 2018. Andersen Tax Digest Businessday, $10^{\text {th }}$ April, 2018. [Online]. Available at: 
https://ng.andersen.com/a-review-of-the-lagos-state-land-use-chargelaw-2018/. Accessed: $9^{\text {th }}$ November, 2020. pp.9.

Fjeldstad, O.H., Ali, M. \& Goodfellow, T. (2017). Taxing the urban boom: Property taxation in Africa. CMI Brief. [Online]. Available at: https://www.cmi.no/publications/6190-taxing-the-urban-boomproperty-taxation-in-africas. Accessed: $14^{\text {th }}$ November, 2020.

Fjeldstad, O.H., Ali, M. \& Katera, L. (2019). Policy implementation under stress: Central-local government relations in property tax administration in Tanzania, Journal of Financial Management of Property and Construction, 24(2), pp.129-147. DOI: 10.1108/JFMPC-10-2018-0057.

Fjeldstad, O.H., Katera, L. \& Ngalewa, E. (2009). Outsourcing Revenue Collection to Private Agents: Experiences from Local Government Authorities in Tanzania. REPOA Special Paper No. 28-2009. [Online]. Dar es Salaam: Mkuki Na Nyota Publishers. Available at: https://www.cmi.no/publications/file/3341-private-taxcollection.pdf. Accessed: $14^{\text {th }}$ November, 2020.

Franzsen, R. \& McCluskey, W.J. (Eds). (2017a). Property Tax in Africa: Status, Challenges and Prospects. Cambridge, MA: Lincoln Institute of Land Policy.

Franzsen, R. \& McCluskey, W.J. (2017b). North and Northeast Africa. In Franzsen, R \& McCluskey, W. (Eds), Property Tax in Africa: Status, Challenges and Prospects. Cambridge, MA: Lincoln Institute of Land Policy, pp.531-547.

Franzsen, R., McCluskey, W.J. \& Nhaginde, V. (2017). Cabo Verde. In Franzsen, R \& McCluskey, W. (Eds), Property Tax in Africa: Status, Challenges and Prospects. Cambridge, MA: Lincoln Institute of Land Policy, pp.131-137.

Franzsen, R. \& Youngman, J.M. (2009). Mapping Property Taxes in Africa. [Online]. Available at:

https://www.shareweb.ch/site/DDLGN/Documents/Mapping\%20pro perty $\% 20$ taxes $\% 20 \mathrm{in} \% 20$ Africa_Franzsen $\% 20$ and $\% 20$ Youngman $\%$ 20(2009).pdf. Accessed: 14 ${ }^{\text {th }}$ November, 2020.

Gerring, J. (2007). Case Study Research, Principles and Practices. Cambridge: Cambridge University Press.

Goodfellow, T. (2015). Taxing the urban boom: property taxation and land leasing in Kigali and Addis Ababa. ICTD Working Paper 38. [Online]. Available at: https://www.ictd.ac/publication/taxing-theurban-boom-property-taxation-and-land-leasing-in-kigali-and-addisababa/. Accessed: $11^{\text {th }}$ June, 2021.

Goodfellow, T. (2017). Taxing property in a neo-developmental state: The politics of urban land value capture in Rwanda and Ethiopia. African Affairs, 116(465), pp.549-572.

DOI: $10.1093 /$ afraf/adx020.

Jibao, S. (2017). Ghana. In Franzsen, R. \& McCluskey, W. (Eds), Property Tax in Africa: Status, Challenges and Prospects. Cambridge, MA: Lincoln Institute of Land Policy. pp.218-227.

Kayuza, H. (2014). The Dilemma of Implementing Property Taxation in Tanzania amidst Unending Search for Yielding Strategy. Lessons 
from Dar es Salaam LGAs. Journal of Land Administration in Eastern Africa, 2(1), pp.117-127. [Online]. Available at https://landportal.org/library/resources/dilemma-implementingproperty-taxation-tanzania-amidst-unending-search-yielding. Accessed $13^{\text {th }}$ November, 2020.

Lagos State Government. (2020). LASG reviews Land Use Charge Rate. Lagos State Government. [Online]. Available at: https://lagosstate.gov.ng/blog/2020/08/05/lasg-reviews-land-usecharge-rates/ Accessed $10^{\text {th }}$ April, 2021.

Massawe, H.T. (2020). Regulation of Property Tax in Tanzania: Legal and Administrative Challenges, KAS African Law Study Library, 7(3), pp.425-438. [Online]. Available at: https://www.nomoselibrary.de/10.5771/2363-6262-2020-3-424/regulation-of-propertytax-in-tanzania-legal-and-administrative-challenges-jahrgang-72020-heft-3. Accessed: 24 ${ }^{\text {th }}$ March, 2021.

McCluskey, W.J. \& Franzsen, R.D. (2016). Property tax reform in Africa: Challenges and potential. In proceedings of the 2016 World Bank Conference on Land and Poverty. Washington DC. 14-18 ${ }^{\text {th }}$ March, 2016.

McCluskey, W.J. \& Huang, C.Y. (2019). The role of ICT in property tax administration: Lessons From Tanzania. Bergen: CMI. [Online] Available at: https://www.cmi.no/publications/6880-the-role-of-ictin-property-tax-administration-lessons- from-tanzania.CMI Brief No 6. Accessed: $13^{\text {th }}$ November, 2020.

McCluskey, W.J. \& Jibao, S. (2017). The Gambia. In Franzsen, R \& McCluskey, W. (Eds), Property Tax in Africa: Status, Challenges and Prospects. Cambridge, MA: Lincoln Institute of Land Policy, pp.207217.

Namangaya, A. (2018). Practices in Institutionalizing GIS for Revenue Mobilization: The Case of Secondary Cities in Tanzania. Current Urban Studies 6(4), pp.559-572. DOI: 10.4236/cus.2018.64030.

Odimegwu, C. N., Anyakora, M. I. \& Odumodu, A. I. (2018) A comparative analysis of Land Use Charge Laws in Anambra, Edo, Lagos and Enugu States, Nigeria, African Journal of Environmental Research, 1(2), pp.14-24.

Oluwadare, C. \& Ojo, O. (2014). Database Creation for Tenement Rate Collection: The Role of GIS, The Pacific Journal of Science and Technology, 15(1), pp.190-199.

Plimmer, F. \& McCluskey, J. (2010). The basis and administration of the property tax: what can be learned from International Practice? In proceedings of the FIG Congress 2010: facing the challenges: building capacity. [Online]. Available at: https://www.fig.net/resources/proceedings/fig_proceedings/fig2010/ papers/ts01f/ts01f plimmer mccluskey 4174.pdf. Accessed: $3^{\text {rd }}$ June, 2018.

Rwandan Revenue Authority. (2018). Taxes for Growth and Development. Rwandan Revenue Authority. [Online]. Available at: https://www.rra.gov.rw/fileadmin/user_upload/rra immovable_prop erty.pdf. Accessed: $3^{\text {rd }}$ April, 2021. 
Soressa, A.L. \& Gebreslus, B.T. (2009). Property taxation in North-East Africa: case study of Ethiopia. Lincoln Institute of Land Policy Working Paper. [Online]. Available at:

https://www.lincolninst.edu/publications/working-papers/propertytaxation-north-east-africa. Accessed: $14^{\text {th }}$ November, 2020.

Turnbull, D., Chugh, R. \& Luck, J. (2021). The Use of Case Study Design in Learning Management System Research: A Label of Convenience? International Journal of Qualitative Methods, 20, pp.1-11.

UN-Habitat. (2011). Land and Property Tax: A Policy Guide. Nairobi: UNHabitat. [Online]. Available at: https://unhabitat.org/sites/default/files/download-managerfiles/Land\%20and\%20Property\%20Tax.pdf. Accessed: $5^{\text {th }}$ April, 2021.

UN-Habitat. (2020). World Cities Report 2020: The Value of Sustainable Urbanization. Nairobi: UN-Habitat. [Online]. Available at: https://unhabitat.org/World\%20Cities\%20Report\%202020. Accessed $21^{\text {st }}$ November, 2020.

United Nations. (2014). The state of African cities: Re-imagining sustainable urban transitions. [Online]. Available at: https://unhabitat.org/stateof-african-cities-2014-re-imagining-sustainable-urban-transitions.

Accessed: 14 ${ }^{\text {th }}$ November, 2020.

Uwayezu, E. \& de Vries, W. (2020). Access to affordable houses for the lowincome urban dwellers in Kigali: Analysis based on sales prices. Land, 9(3), pp.85-117. DOI:10.3390/land9030085.

World Bank. (2017). World Bank Doing Business Reports 2017. Washington, DC: The World Bank Group. [Online]. Available at: https://www.doingbusiness.org/en/reports/global-reports/doingbusiness-2017. Accessed: 12 ${ }^{\text {th }}$ July, 2018. 